\title{
Streamflow predictions in regulated river systems: hydrological non-stationarity versus anthropogenic water use
}

\author{
D. Dutta, S. Kim, J. Vaze, and J. Hughes \\ Land and Water Flagship, CSIRO, Canberra, Australia \\ Correspondence to: D. Dutta (dushmanta.dutta@csiro.au)
}

Received: 27 March 2015 - Accepted: 27 March 2015 - Published: 12 June 2015

\begin{abstract}
Streamflow in a regulated river system is highly influenced by storage regulations and anthropogenic water use in addition to climate variability. Thus, changes in climate-streamflow relationships and dominant hydrological processes over time are difficult to quantify in a regulated system without partitioning influence of storage regulation and anthropogenic water uses. This requires a robust regulated river system model, which takes into consideration of both hydrological and man-made flow regulation processes, as well as anthropogenic water uses. In this study, a newly developed large-scale river system model (called "AWRA-R") was used to assess the influence of both anthropogenic and climate variability/change on streamflow non-stationarity in the Murray Darling Basin (MDB). MDB is one of the highly regulated basins in Australia with multiple large and small storages developed primarily for supplying water to irrigated agriculture. The modelling was undertaken for the period of 1950-2010, which includes rapid water resources development and both wet and dry climate. The AWRA-R model was calibrated for a reasonably long period and then, validated on an independent period. The calibrated parameters were used to simulate streamflow under current and pre-development conditions to analyse the streamflow variability and influence of climate variability and anthropogenic development on streamflow trend. This paper briefly introduces the model and the method used for assessing streamflow variability under natural and developed conditions and presents the results and findings.
\end{abstract}

\section{Introduction}

There are numerous studies that have been conducted to assess the potential impacts of climate change on rainfall and runoff at global to regional to catchment scales (Chiew et al., 2014; Vaze et al., 2010; Kamruzzaman et al., 2011; Rossi et al., 2009). Many of these studies have demonstrated the impact of climate change on global and regional climatic systems and alteration of hydrological processes as a result of that. It is acknowledged by many scientists and water managers that the assumption of stationarity in rainfall-runoff modelling is no longer valid (Chiew et al., 2014). Most of the studies related to hydrological non-stationarity have mainly focussed on un-regulated headwater catchments, which are less influenced by anthropogenic water use. From a water resources management perspective, streamflow is of key interest to water managers and most of the river basins are regulated with multiple storages for water resources management around the world. For example, Australia has the highest per capita surface water storage capacity in the world to sustain agricultural production and water supplies with over 500 large dams with storage capacity of approximately $85000 \mathrm{GL}$ and many thousands of additional farm dams (ABS, 2010). Hydrological processes in large river basins are strongly affected by human activities in addition to climatic change (Rossi et al., 2009). In particular, streamflow in a regulated river basin is highly influenced by storage regulations and anthropogenic water use in addition to climate variability and change. Thus, changes in climate-runoff relationships and dominant hydrological processes over time are difficult to quantify in a regulated system without partitioning influence of storage regulation and anthropogenic water uses. This requires a robust regulated river system model, which takes into consideration of both hydrological and man- 
made flow regulation processes, as well as anthropogenic water uses.

A large-scale river system (AWRA-R) model was developed and implemented for water accounting in Australia (Dutta et al., 2014, 2015). The model includes major hydrological processes, anthropogenic water utilisation and storage routing that influence the streamflow in regulated rivers. It incorporates urban diversions and includes an irrigation model to compute water diversion for irrigation (Hughes et al., 2013) and an inundation model to compute overbank flow (Teng et al., 2015; Dutta et al., 2013). The river model is linked to a landscape model (AWRA-L, Vaze et al., 2013) and allows to quantify different surface and groundwater fluxes and stores associated with streamflow at a river basin scale.

The main issue investigated in this study is the estimation of the anthropogenic impact on streamflow using AWRA$\mathrm{R}$ river system model. The Murray Darling Basin (MDB), a highly regulated basin with a large number of large and small storages used for irrigation diversions, is selected as the study area. The AWRA-R model was first calibrated for a reasonably long period and then, validated on an independent period for the entire MDB.

The calibrated parameters were used to simulate streamflow under current and pre-development conditions to analyse the streamflow variability and influence of climate change and anthropogenic development for the period of 1950-2010. This period covers rapid water resources development in the basin and both wet and dry climate. The paper briefly introduces the model and the method used for assessing streamflow variability under natural and developed conditions and discusses the results and findings.

\section{Study area}

The study area is the Murray Darling Basin (MDB) in Australia, which covers an area of about 1 million $\mathrm{km}^{2}(1450 \mathrm{~km}$ long and $1000 \mathrm{~km}$ wide) and consists largely of plains rising to the Great Dividing Range on its eastern and southern rim. The MDB river system is a highly complex and mostly regulated system covering four states (Queensland, New South Wales (NSW), Victoria and South Australia) and one territory (ACT) (CSIRO, 2008). The MDB is often referred to as Australia's "food bowl", with agriculture covering up to $80 \%$ of the land area in the Basin (Connell and Grafton, 2011; Griffiths and Edraki, 2013). It utilises about $70 \%$ of all water used for agriculture across the nation and accounts for $40 \%$ of Australia's agricultural production. In the MDB, large dams can store a maximum of 24339 GL; this comprises nearly a third (29\%) of Australia's large dam storage capacity (ABS, 2008). The water stored in these dams is predominantly used for irrigation in agriculture. In addition to large dams, many farm dams exist in the MDB. These hill-slope farm dams can store up to

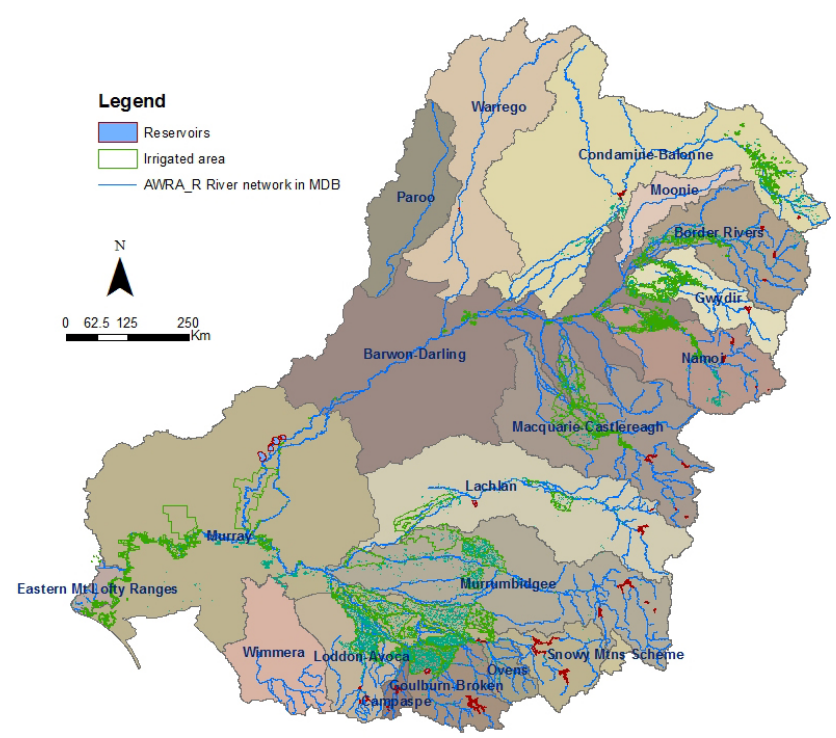

Figure 1. Map showing 18 regions of AWRA-R within the MDB along with the AWRA-R river network, modelled irrigated areas and major reservoirs.

$2200 \mathrm{GL}$ in the Basin and can act as a significant interceptor to run-off, potentially reducing stream flow (ABS, 2008). The entire MDB was divided into 18 contiguous regions in the Murray-Darling Basin Sustainable Yields (MDBSY) Project (CSIRO, 2008) (Fig. 1). These regions, namely Paroo, Warrego, Condamine-Balonne, Moonie, Border Rivers, Gwydir, Namoi, Macquarie-Castlereagh, Barwon-Darling, Lachlan, Murrumbidgee, Murray, Ovens, Goulburn-Broken, Campaspe, Loddon-Avoca, Wimmera and Eastern Mount Lofty Ranges, are primarily the drainage basins of the Murray and the Darling rivers and their tributaries.

\section{AWRA-R model}

\subsection{Brief description}

The AWRA-R model is designed using a node-link concept (Welsh et al., 2013; Dutta et al., 2014), where a river system is schematised into a simplified river network using a nodelink structure. The river network begins and ends with a node, and all nodes are interconnected by links. A link is used for transfer of flow between two nodes with or without routing and transformation. Runoff from gauged or ungauged tributaries or local contributing area between two nodes is fed into the connecting link as an inflow at the relevant location and all other physical processes (such as diversions, groundwater fluxes, overbank flow) occurring between the two nodes are incorporated in the link. Figure 2 shows a conceptual river reach of AWRA-R. 


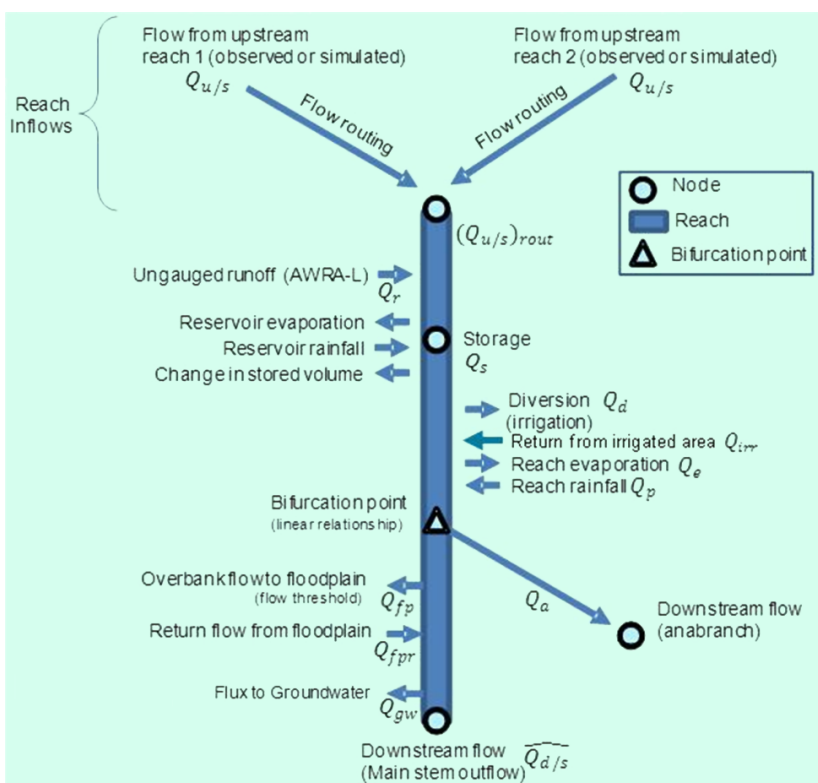

Figure 2. Conceptual representation of a river reach within AWRAR.

For a river reach, the general form of the water balance equation can be described as follows:

$$
\begin{aligned}
\hat{Q}_{\mathrm{d} / \mathrm{s}} & =\left(Q_{\mathrm{u} / \mathrm{s}}\right)_{\text {rout }}+Q_{\mathrm{r}}+Q_{\mathrm{s}}-Q_{\mathrm{d}}+Q_{\mathrm{irr}}-Q_{\mathrm{u}} \\
& +Q_{\mathrm{p}}-Q_{\mathrm{e}}-Q_{\mathrm{a}}-Q_{\mathrm{fp}}+Q_{\mathrm{fpr}}-Q_{\mathrm{gw}}
\end{aligned}
$$

where, $\hat{Q}_{\mathrm{d} / \mathrm{s}}$ is the estimated flow at the downstream gauge, $\mathrm{Q}_{\mathrm{u} / \mathrm{s}}$ is concurrent flow at the upstream gauges (including gauged tributaries), $\left(Q_{\mathrm{u} / \mathrm{s}}\right)_{\text {rout }}$ is upstream inflow following routing, $Q_{\mathrm{r}}$ is the runoff locally generated from the local ungauged catchment, $Q_{\mathrm{s}}$ is the contribution from any storages including rainfall on storage area, evaporation from storage area and change in storage volume, $Q_{\mathrm{d}}$ is the loss due to irrigation diversion, $Q_{\text {irr }}$ is the total return flow from irrigated area, $Q_{\mathrm{u}}$ is the net loss due to urban diversion, $Q_{\mathrm{p}}$ and $Q_{\mathrm{e}}$ are the fluxes to and from the river due to rainfall and evaporation, respectively, $Q_{\mathrm{a}}$ is the flow diverted to anabranches, $Q_{\text {fp }}$ is overbank flow to floodplain, $Q_{\mathrm{fpr}}$ is return flow from floodplain, $Q_{\mathrm{gw}}$ is the flux from river to groundwater.

AWRA-R consists of the following major components that are used to compute different parts of the water balance equation (Eq. 1):

- rainfall-runoff modelling for ungauged runoff (using/through AWRA-L);

- streamflow routing;

- floodplain inundation modelling;

- irrigation modelling;

- river and groundwater interaction modelling;
- storage routing;

- rainfall and evaporation fluxes from river;

- anabranch flow;

- urban water use.

The details of each of the above components of the model including governing equations are elaborated in Dutta et al. (2014).

\subsection{Model set up}

The node-link networks for different sub-regions of MDB are developed based on the streamflow gauges with at least 5 years of daily records. The network for the entire basin has included a total of 485 nodes, out of which 187 are headwater nodes. The irrigated area maps derived from remotely sensed data for multiple years (between 2000-2010) and 1:100-year return period inundation extent map were used to identify the river reaches with irrigation diversion and overbank flow, respectively. The AWRA-R model for the MDB included 58 reaches with irrigation diversion and 196 floodplain reaches with overbank flow. The total number of reservoirs included in the model is 45 , which are mainly large reservoirs with daily data available. Some of the small reservoirs and farm dams are not included in the model due to non-availability of data. The model also did not incorporate water diversion other than irrigation diversion (such as urban water and stock and domestic, which are relatively very small compared to irrigation diversion) due to poor data quality.

The daily rainfall data was obtained from gridded AWAP database from the Australian Bureau of Meteorology (BoM). Daily time series of potential evapotranspiration (PET) and ungauged runoff were obtained from the AWRA Landscape model (AWRA-L) (Viney et al., 2014), which is a gridded continental scale model of $\sim 5 \mathrm{~km} \times 5 \mathrm{~km}$ resolution. The AWRA-L model is calibrated only against streamflow data in a large number of un-impaired headwater catchments. The simulated runoff by the calibrated AWRA-L model is used to calculate catchment averaged runoff from ungauged catchments for AWRA-R modelling.

The AWRA-R model was calibrated and validated against the observed daily streamflow data. Based on the length and quality of the streamflow data at the selected gauges and climatic variability in the MDB region, the period of 1970 1991, covering both wet and dry climate, was selected for calibrating AWRA-R model. A more recent period of 1992 2010 was selected for validating the model. This period included the millennium drought in MDB from 2000-2009 (Kirby et al., 2012).

The calibrated model was used to simulate streamflow for the period of 1950-2010 for two scenarios: (i) current and (ii) pre-development. For both simulation runs, same rainfall time series and inputs from AWRA-L model such as 


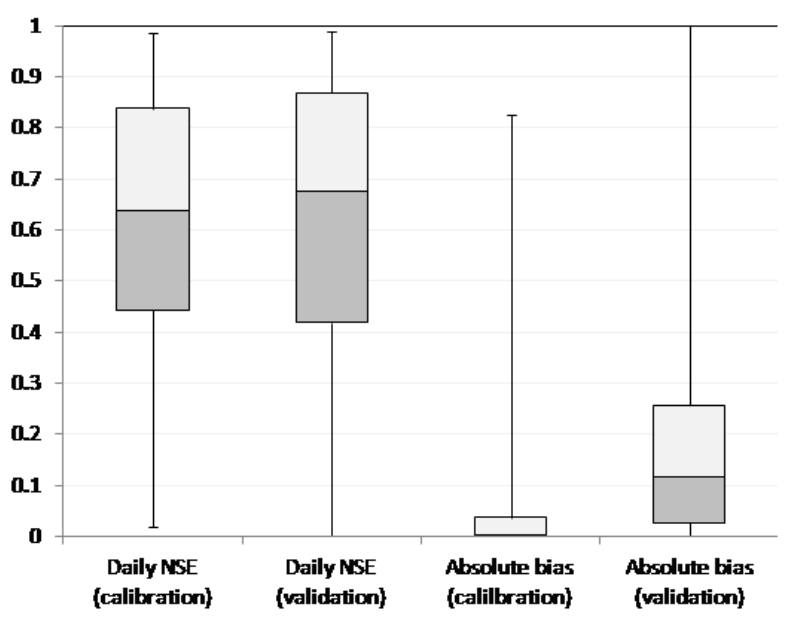

Figure 3. Statistics of AWRA-R model performance in MDB during the calibration and validation periods.

runoff and PET were used. As the AWRA-L model is calibrated only in un-impaired headwater catchments, the influence of anthropogenic development has very little impact on AWRA-L model calibration and gridded runoff that are used for AWRA-R modelling. The other input datasets of the calibrated model remain the same for the current scenario run. For the pre-development simulation run, the irrigation diversion and storages were not included in AWRA-R to represent pre-development settings by minimising the influence of anthropogenic developments and water use.

\section{Results}

\subsection{Model calibration and validation}

The summary statistics of the model performance, daily Nash-Sutcliffe Efficiency (NSE) and absolute bias, during the calibration and validation periods are presented in Fig. 3 . In the calibration, the model performed reasonably well in the MDB with the median daily NSE of 0.64. The median value of absolute bias during the calibration was less than $1 \%$ for the MDB. The calibrated model performed extremely well under the validation mode with the median daily NSE of 0.68 . This was consistent with the results under the calibration mode. In the validation, the median value of absolute bias was $11 \%$ for the MDB. The bias was relatively higher in the validation period compared to the calibration period. The annual average mass balance error (which was calculated using Eq. 1) was less than $1 \%$ for both calibration and validation periods. The calibration and validation results and mass balance error for each of the sub-regions within MBD are presented and discussed in detail in Dutta et al. (2015).

\subsection{Impacts of climate variability/change and anthropogenic activities on streamflow}

In order to identify the principal modes of variability that characterise streamflow in the MDB, hydrological annual time-series were compared to precipitation, as the most representative hydrological signal of climate fluctuations. Figure 4 presents the annual average rainfall and stream flow for the MDB for current and pre-development scenarios for the period of 1950-2010. The average rainfall shows a decreasing trend over the period. The decreasing trend in streamflow is much more significant than rainfall, highlighting the non-stationarity in the rainfall-streamflow relationship in the MDB as reported in Chiew et al. (2014). As can be seen from the streamflow plots and trend lines for the current and predevelopment scenarios, the decreasing trend in streamflow is exacerbated by the anthropogenic development and water use in the basin over the modelling period. There is more than $5 \%$ difference in the mean value of streamflow under the current and pre-development scenario. Much of the storage capacity (other than farm dams) within the Basin was constructed between the mid-1950s and 1990 and now account for about $80 \%$ of the water-storage capacity in the Basin (Connell and Grafton, 2011)

The analysis period (1950-2010) can be divided into three periods based on climatic characteristics in South-east Australia over this period: (i) persistent wet period (19501977), (ii) average climate (1978-1996) and (iii) millennium drought period (1997-2009). Table 1 shows the mean values of annual rainfall and streamflow in the MDB under the current and pre-development scenarios for these three periods and the changes in percentage over the long-term average. The long-term averages of annual streamflows for the current and pre-development scenarios are calculated based on the modelled outputs for the period of 1911-2014. The change in streamflow is most prominent (34\% reduction) over the period of the millennium drought. The difference between streamflow for the current and pre-development scenarios is only $2 \%$ in the period of 1950-1977, however it increases to over $7 \%$ in the next two periods during which a number of large storages (such as Chaffey, Split Rock, Pindari) were built or enlarged and water use for irrigation increased significantly. This highlights the significant influence of anthropogenic activities and water use on non-stationarity of the rainfall-streamflow relationship in the basin.

The climate characteristics in the MDB vary significantly from north to south; with summer-dominated rainfall in the north to winter-dominated rainfall in the south. Similarly, anthropogenic developments in the MDB are spatio-temporally non-uniform. Hence, the long-term trends in rainfall and streamflow and their relationship vary widely between different regions. To analyse the variations from north to south and between highly and less developed regions, four catchments were selected for further analysis. Two catchments are from the north: Paroo and Condamine-Balonne and two 



Figure 4. Average annual rainfall and streamflow in MDB under current and pre-development scenarios for the period of 1950-2010.

Table 1. Mean annual rainfall and streamflow under current and pre-development scenarios in MDB for three different periods and their changes over the long-term mean.

\begin{tabular}{lrrrr}
\hline & $\begin{array}{r}\text { Rainfall } \\
(\mathrm{mm})\end{array}$ & $\begin{array}{r}\text { Streamflow: } \\
\text { current (GL) }\end{array}$ & $\begin{array}{r}\text { Streamflow: } \\
\text { pre-develop- } \\
\text { ment (GL) }\end{array}$ & $\begin{array}{r}\text { Difference: } \\
\text { current and pre- } \\
\text { development }\end{array}$ \\
\hline Long-term average (1911-2014) & 530 & 36 & 37 & $2 \%$ \\
I: $1950-1977$ & 572 & 45 & 46 & $7 \%$ \\
Changes in I from long-term mean & $8 \%$ & $26 \%$ & 39 & $8 \%$ \\
II: $1978-1996$ & 536 & 36 & & \\
Changes in II from long-term mean & $1 \%$ & $-1 \%$ & 26 & \\
III: $1997-2009$ & 506 & 24 & & \\
Changes in III from long-term mean & $-5 \%$ & $-34 \%$ & & \\
\hline
\end{tabular}

catchments are from the south: Ovens and Goulburn-Broken. Paroo and Ovens are largely un-regulated systems with a number of small storages and total diversions of water for irrigation in the two basins are negligible. In AWRA-R modelling, both of these catchments are treated as un-regulated systems without any diversion. Due to that, ratio of streamflow to rainfall is much larger in these two basins compared to the whole MDB. This can be clearly seen from the plots of annual average rainfall and streamflow in the two basins as shown in Fig. 5. In Paroo, the trends in rainfall and streamflow are very similar. In Ovens, rainfall-streamflow relationships do exhibit non-stationarity, but to a much lesser extent compared to the overall MDB. As expected, there is no difference between annual average streamflow for the current and pre-development scenarios in these two catchments.

As shown in Fig. 6, rainfall and streamflow relationships in the two highly regulated catchments (Condamine-Balonne and Goulburn-Broken) show non-stationarity with very dis- tinct trends in rainfall and streamflow over the period of 1950-2010. The decreasing trends in streamflow are highly influenced by the development of storages and irrigation diversion starting from the early 1970s. The influence is relatively more prominent in Goulburn-Broken, where irrigation diversion is relatively larger compared to CondamineBalonne. As can be seen from Table 2, differences in streamflow between the current and pre-development scenarios are relatively low $(\sim 2 \%)$ for the early period of 1950-1977, but increased significantly (by over $10 \%$ ) for the two subsequent periods. The results presented in Table 2 show that one third of the decreasing trends in the streamflow in the two basins can be attributed to the anthropogenic development and water use. 

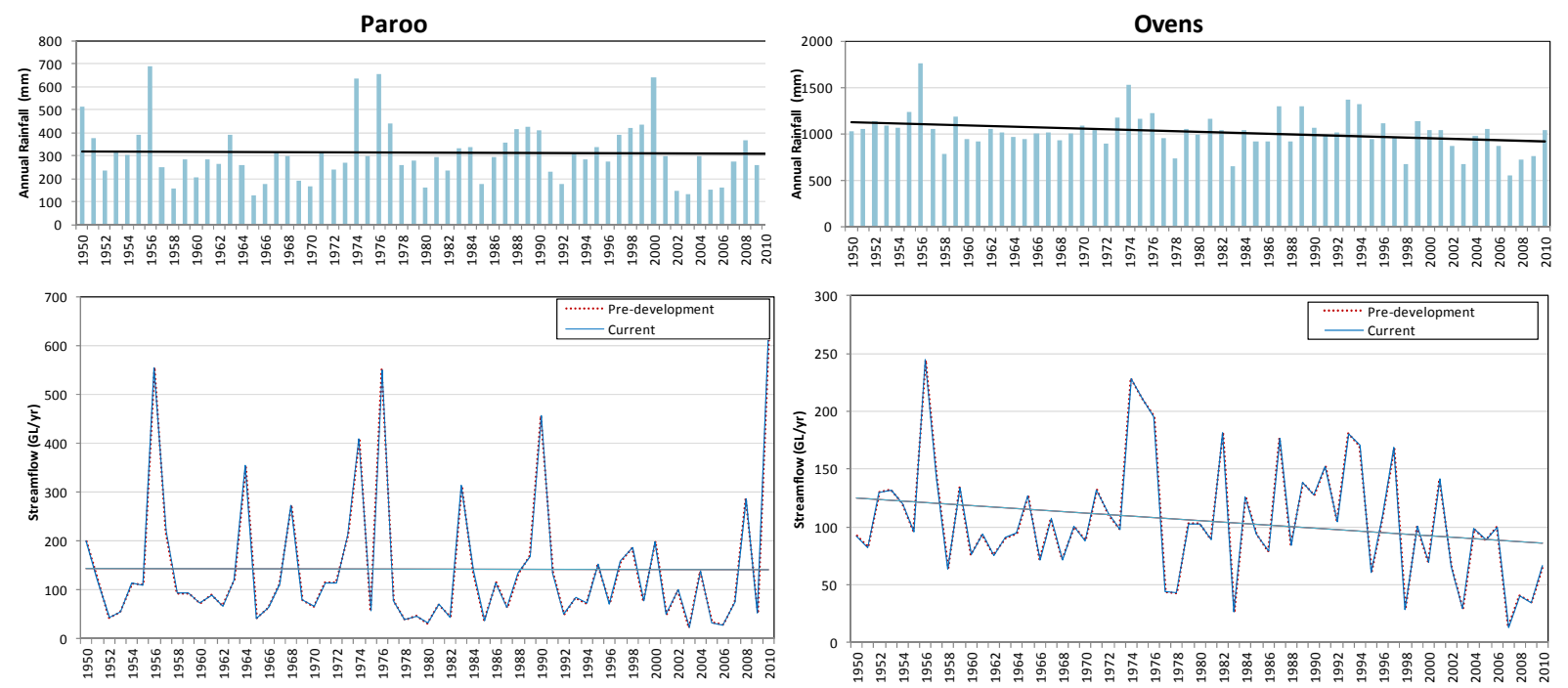

Figure 5. Average annual rainfall and streamflow in Paroo and Ovens under current and pre-development scenarios for the period of 19502010.

Table 2. Mean annual rainfall and streamflow under current and pre-development scenarios in MDB for three different periods and their changes over the long-term mean.

\begin{tabular}{|c|c|c|c|c|c|c|c|c|}
\hline \multirow[b]{2}{*}{ Period } & \multicolumn{4}{|c|}{ Condamine-Balonne } & \multicolumn{4}{|c|}{ Goulburn } \\
\hline & Rainfall & $\begin{array}{r}\text { Streamflow: } \\
\text { pre- } \\
\text { development }\end{array}$ & $\begin{array}{r}\text { Streamflow: } \\
\text { current }\end{array}$ & $\begin{array}{r}\text { Difference: } \\
\text { current and pre- } \\
\text { development }\end{array}$ & Rainfall & $\begin{array}{r}\text { Streamflow: } \\
\text { pre- } \\
\text { development }\end{array}$ & $\begin{array}{r}\text { Streamflow: } \\
\text { current }\end{array}$ & $\begin{array}{r}\text { Difference: } \\
\text { current and pre- } \\
\text { development }\end{array}$ \\
\hline 1911-2014 & 510 & 20 & 19 & & 628 & 65 & 62 & \\
\hline I: $1950-1977$ & 551 & 25 & 24 & $2 \%$ & 687 & 79 & 78 & $1 \%$ \\
\hline Changes in period I from long-term mean & $8 \%$ & & $31 \%$ & & $9 \%$ & & $26 \%$ & \\
\hline II: $1978-1996$ & 513 & 20 & 18 & $10 \%$ & 639 & 71 & 63 & $11 \%$ \\
\hline Changes in period I from long-term mean & $1 \%$ & & $-7 \%$ & & $2 \%$ & & $2 \%$ & \\
\hline III: $1997-2009$ & 511 & 10 & 7 & $28 \%$ & 534 & 37 & 32 & $14 \%$ \\
\hline Changes in period I from long-term mean & $0 \%$ & & $-61 \%$ & & $-15 \%$ & & $-48 \%$ & \\
\hline
\end{tabular}

\section{Discussion}

Non-stationarity in rainfall and streamflow and their relationship are clearly evident from the simulated results in the MDB. Vaze et al. (2010) have demonstrated the same in a number of unregulated catchments in South-east Australia. Petheram et al. (2011) have explained the changes in hydrological processes through reduced connectivity between surface and groundwater in millennium drought period in several un-regulated headwater catchments in the MDB and the impact of that on streamflow reduction. Vaze et al. (2010) demonstrated that due to this non-stationarity and non-representativeness of the calibrated models when used under drastically different climatic conditions compared to the climate during calibration period, the assumption that rainfall-runoff models calibrated over a historical period are valid for use in the future under climate-change regime is not valid in the MDB. The results of AWRA-R modelling in MDB have shown that there is a significant influence of anthropogenic development and water use on streamflow trends in regulated basins. For example, in the Condamine-Balonne and Goulburn-Broken systems, anthropogenic development and water use have contributed to more than one-third of the overall decline in streamflow. Some of the smaller storages (such as farm dams, ring tanks) and water diversions (such as urban and stock and domestic) were not incorporated in AWRA-R modelling due to non-availability of suitable data. The influence of anthropogenic development and water use is likely to be even bigger on streamflow non-stationarity in regulated systems with incorporation of these additional information in the modelling.

\section{Summary}

This study used the newly developed AWRA-R river system model to analyse the influence of anthropogenic development and water use on streamflow and to partition this influence from climate variability/change impact on streamflow in a regulated river system. The model was implemented in the Murray-Darling Basin, a highly regulated basin with a 

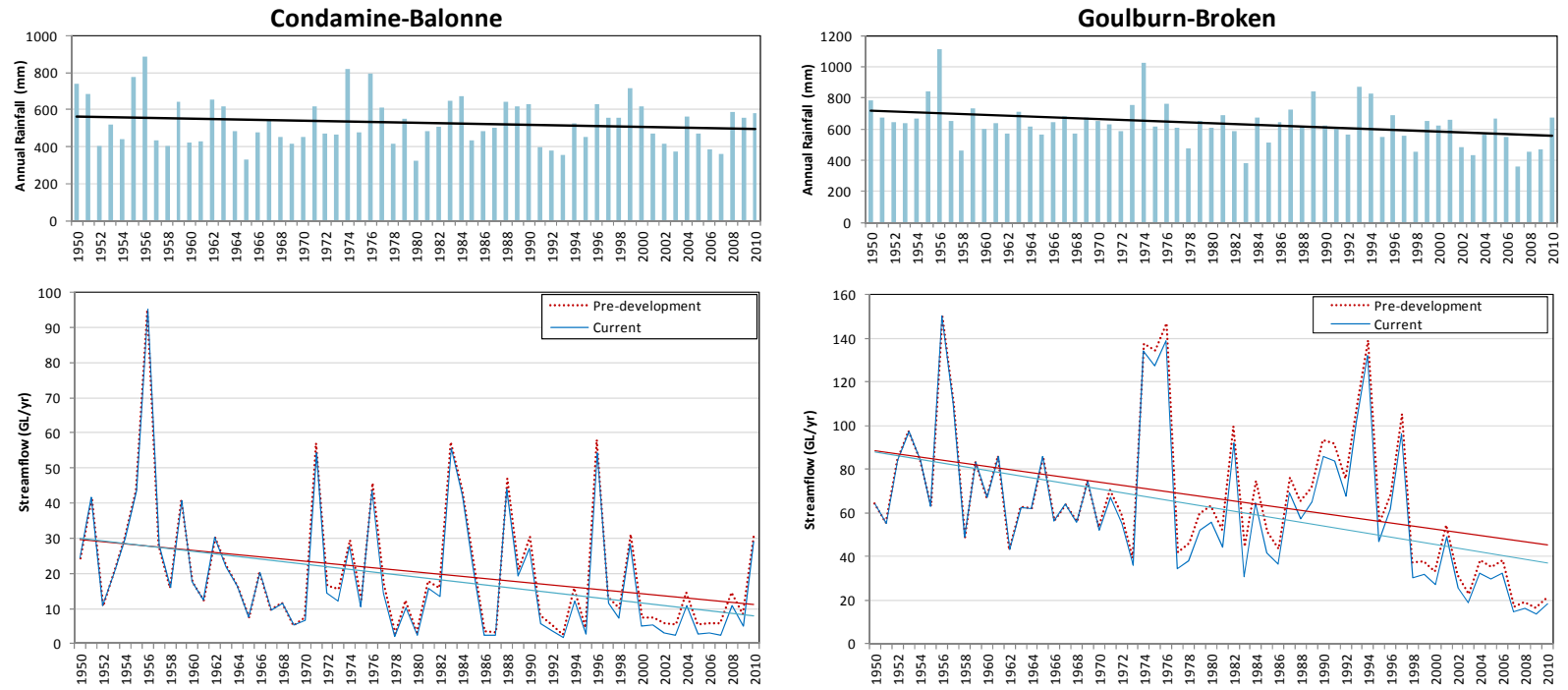

Figure 6. Average annual rainfall and streamflow in Condamine-Balonne and Goulburn-Broken under current and pre development scenarios for the period of 1950-2010.

number of large storages built for water diversion for irrigated agriculture. The results have demonstrated that the water storages and anthropogenic water use have significant influence on trends in streamflow. The influence is not-uniform across the basin. The results in the Condamine-Balonne and Goulburn-Broken systems, two of the highly regulated systems, show that the storages and irrigation diversion have contributed more than $30 \%$ of the overall declining trend in streamflow over the period of 1970-2010.

This study highlights the importance of consideration of the influence of anthropogenic development and water use in streamflow trends and rainfall-runoff non-stationarity analysis in regulated river basins. The AWRA-R modelling system, through consideration of both hydrological and manmade flow regulation processes, has allowed to quantify the influence of storages and water use on long-term trend in streamflow in a regulated system.

\section{References}

ABS: Year Book Australia: Australian Bureau of Statistics, 2008, available at: http://www.abs.gov.au/ausstats/abs@.nsf/0/ D53408834D6C846FCA2573D2001066F3?opendocument (last access: 15 March 2015), 2008.

ABS: Inland Waters: Water Storage, Australian Bureau of Statistics, available at: http://www.abs.gov.au/ausstats/abs@.nsf/Lookup/ bySubject/1370.0 2010 Chapter Waterstorage(6.3.6.2) (last access: 15 March 2015), 2010.

Chiew, F., Potter, N., Vaze, J., Petheram, C., Zhang, L., Teng, J., and Post, D.: Observed hydrologic non-stationarity in far southeastern Australia: implications for modelling and prediction, Stoch. Environ. Res. Risk. Assess., 28, 3-14, 2014.
CSIRO: Water availability in the Murray-Darling Basin. A report to the Australian Government from the CSIRO Murray-Darling Basin Sustainable Yields Project, CSIRO, Australia, 2008.

Connell, D. and Grafton, R. Q.: Basin Futures: Water reform in the Murray-Darling Basin, ANU E-Press, 2011.

Dutta D., Teng, T., Vaze, J., Lerat, J., Hughes, J., and Marvanek, S.: Storage-based Approaches to Build Floodplain Inundation Modelling Capability in River System Models for Water Resources Planning and Accounting, J. Hydrol., 504, 12-28, 2013.

Dutta, D., Vaze, J., Kim, S., Hughes, J., Teng, J., Yang, A., Crosbie, R., and Frost, A.: AWRA-LGR Description and Integration: Current System and Future Plans, CSIRO Water for a Healthy Country Flagship, Australia, 30 pp., 2014.

Dutta, D., Vaze, J., Kim, S., Hughes, J., and Yang, A.: A processbased river system model at a continental scale for water accounting, Proceedings of the 36th IAHR World Congress, 28 June-3 July 2015, The Hague, the Netherlands, 2015.

Griffiths, R. and Edraki, M.: A Review of Agricultural Water use in Australia, The Bureau of Meteorology, Australian Government, 2013.

Hughes, J., Mainuddin, M., Lerat, J., and Dutta, D.: An irrigation model for use in river systems modelling, Proceedings of the 20th International Congress on Modelling and Simulation, Adelaide, Australia, 1-6 December 2013, 2464-2470, 2013.

Kamruzzaman, M., Beecham, S., and Metcalfe, A.: Nonstationarity in rainfall and temperature in the Murray Darling Basin, Hydrol. Process., 25, 1659-1675, 2011.

Kirby, M., Connor, J., Bark, R., Qureshi, E., and Keyworth, S.: The economic impact of water reductions during the Millennium Drought in the Murray-Darling Basin, 56th AARES annual conference, Fremantle, Western Australia, 7-10 February, 2012.

Petheram, C., Potter, N., Vaze, J., Chiew, F. H. S., and Zhang, L.: Towards better understanding of changes in rainfall-runoff relationships during the recent drought in south-eastern Australia, 19th MODSIM Congress, available at: http://mssanz.org. au/modsim11, Perth, Australia, 12-16 December 2011. 
Rossi, A., Massei, N., Laignel, B., Sebag, D., and Copard, Y.: The response of the Mississippi River to climate fluctuations and reservoir construction as indicated by wavelet analysis of streamflow and suspended-sediment load, 1950-1975, J. Hydrol., 377, 237-244, 2009.

Teng, J., Vaze, J., Dutta, D., and Marvanek, S.: Rapid inundation modelling in large floodplains using LiDAR DEM, Water Resour. Manage., doi:10.1007/s11269-015-0960-8, in press, 2015.

Vaze, J., Post, D., Chiew, F., Perraud, J.-M., Viney, N., and Teng, J.: Climate non-stationarity - validity of calibrated rainfall-runoff models for use in climate change studies, J. Hydrol., 394, 447457, 2010.

Vaze, J., Viney, N., Stenson, M., Renzullo, L., Van Dijk, A., Dutta, D., Crosbie, R., Lerat, J., Penton, D., Vleeshouwer, J., Peeters, L., Teng, J., Kim, S., Hughes, J., Dawes, W., Zhang, Y., Leighton, B., Perraud, J. M., Joehnk, K., Yang, A., Wang, B., Frost, A., Elmahdi, A., Smith, A., and Daamen, C.: The Australian Water Resource Assessment System (AWRA), Proceedings of the 20th International Congress on Modelling and Simulation (MODSIM2013), Adelaide, Australia, 1-6 December 2013.
Viney, N., Vaze, J., Crosbie, R., Wang, B., and Dawes, W.: AWRALG version 4.0 technical description of model algorithms and inputs: AWRA-LGv4.0 Technical Report, CSIRO, Australia, 2014.

Welsh, W., Vaze, J., Dutta, D., Rassam, D., Rahman, J., Jolly, I., Wallbrink, P., Podger, G., Bethune, M., Hardy, M., Teng, J., and Lerat, J.: An integrated modelling framework for regulated river systems, Environ. Modell. Softw., 39, 81-102, 2013. 